\title{
Sowing density on oat production physiological parameters
}

\section{Densidades de semeadura sobre os parâmetros fisiológicos de produção em aveia}

\author{
José Antonio Gonzalez da SILVA ${ }^{1 ; 2}$; Rubia Diana MANTAI ${ }^{3}$; Antonio Costa de OLIVEIRA ${ }^{4}$; Cristiano \\ FONTANIVA ${ }^{5}$; Emilio Ghisleni ARENHARDT ${ }^{6}$; Micheli Brasil OLEGÁRIO7; Vinícius de Lima SBERSE ${ }^{8}$ \\ ${ }^{1}$ Projeto de pesquisa desenvolvido pelo grupo de Pesquisa de Sistemas Técnicos de Produção Agropecuária do \\ Departamento de Estudos Agrários da Unijuí \\ 2 Professor do Departamento de Estudos Agrários, Universidade Regional do Noroeste do Estado do Rio Grande do \\ Sul/UNIJUÍ, Rua do Comércio, 3000, Bairro Universitário, CEP 98700-000 ljuí, RS. jagsfaem@yahoo.com.br \\ ${ }^{3}$ Mestranda do Programa de Pós-graduação em Modelagem Matemática, Universidade Regional do Noroeste do Estado \\ do Rio Grande do Sul, Rua do Comércio, 3000, Bairro Universitário, CEP 98700-000 ljuí, RS. rdmantai@yahoo.com.br \\ ${ }^{4}$ Professor do Departamento de Fitotecnia, Faculdade de Agronomia "Eliseu Maciel", Universidade Federal de Pelotas, \\ CEP:96001-970, Capão do Leão, RS. acostol@terra.com.br \\ ${ }_{5}^{5}$ Bolsista de Iniciação Científica/CNPq do Curso de Agronomia da Universidade Regional do Noroeste do Estado do Rio \\ Grande do Sul/UNIJUí, Rua do Comércio, 3000, Bairro Universitário, CEP 98700-000 ljuí, RS. \\ agro_cris@hotmail.com \\ ${ }^{6}$ Autor para correspondência. Mestrando do Programa de Pós-graduação em Agronomia, Centro de Genômica e \\ Fitomelhoramento, Universidade Federal de Pelotas, CEP 96001-970, Pelotas, RS \\ ${ }^{7}$ Bolsista de Iniciação Científica/CNPq do Curso de Agronomia da Universidade Regional do Noroeste do Estado do Rio \\ Grande do Sul/UNIJUí, Rua do Comércio, 3000, Bairro Universitário, CEP 98700-000 ljuí, RS. \\ micheli.olegario@hotmail.com \\ ${ }^{8}$ Bolsista de Iniciação Científica/CNPq do Curso de Agronomia da Universidade Regional do Noroeste do Estado do Rio \\ Grande do Sul/UNIJUÍ, Rua do Comércio, 3000, Bairro Universitário, CEP 98700-000 ljuí, RS. \\ vinisberse@hotmail.com
}

Recebido em: 07-07-2014; Aceito em: 29-01-2015

\begin{abstract}
The optimal sowing density is dependent on the genotype and environmental conditions. This study aims at defining the optimal sowing density that maximizes the hay and grains production for the current short-cycle and reduced height biotype of white oat cultivated on a commercial scale, thus justifying the need for using seeds density superior to the recommended. Experiments were conducted in a complete randomized block design with four replications in a $2 \times 4$ factorial arrangement to cultivate (URS Taura and Brisasul) and sowing density $\left(100,300,600\right.$ and 900 seeds $\left.\mathrm{m}^{-2}\right)$ in the corn/oat and soybean/oat succession system. Regardless of the genotypes tested and cropping system, the current standard biotype of cultivated white oat (short cycle and reduced height) evidence in the physiological characters of production sowing density adjusted around 500 seeds $\mathrm{m}^{-2}$. The results obtained show that the recommendation proposal of seeds superior to the technical indications of oats in the mean cultivated biotype a part from increment the grains production can bring benefits to qualify the crop management.
\end{abstract}

Additional keywords: Avena sativa L.; biomass; $\mathrm{C} / \mathrm{N}$ ratio; harvest index; polynomial equation.

\section{Resumo}

A densidade ideal de semeadura é dependente do genótipo e das condições ambientais. O objetivo do estudo busca definir a densidade ideal de semeadura que maximize a produção de palha e de grãos para o atual biotipo de ciclo curto e estatura reduzida de aveia-branca cultivada em escala comercial. Portanto, justifica-se a necessidade de emprego de uma densidade de sementes superior à recomendação. Foram conduzidos experimentos em delineamento de blocos ao acaso, com quatro repetições, num esquema fatorial $2 \times 4$, para cultivar (URS Taura e Brisasul) e densidade de semeadura (100; 300; 600 e 900 sementes viáveis $\mathrm{m}^{-2}$ ) no sistema de sucessão milho/aveia e soja/aveia. Independentemente dos genótipos testados e do sistema de cultivo, o atual biotipo padrão de aveia-branca cultivada (ciclo curto e estatura reduzida) evidencia, nos caracteres fisiológicos de produção, a densidade de semeadura ajustada ao redor de 500 sementes $\mathrm{m}^{-2}$. Os resultados obtidos mostram que a proposta de recomendação de sementes superior às indicações técnicas da aveia no principal biotipo cultivado, afora incrementar a produção de grãos, pode trazer benefícios em qualificar o manejo da lavoura.

Palavras-chave adicionais: Avena sativa L.; biomassa; equação polinomial; índice de colheita; relação C/N. 


\section{Introduction}

The white oat (Avena sativa L.) is a multipurpose species. Its grains, which are rich in protein and fibers, are intended for human and animal feed, and the whole plant, which is of excellent nutritional value, is commonly used in the preparation of pasture, hay and silage. In southern Brazil and in parts of the Southwest and Midwest regions, it is grown as a grain and straw producing species for soil cover, favoring the implantation of summer crops in the direct sowing system (Crestani, 2011). It is noteworthy that, in this species, the largest straw and grain yield expression is directly related to management techniques, such as plant population, nutrients availability, pest control, among others (Benin et al., 2005).

Plants density per area is a decisive factor in the development of a species if seeking maximum production (Valério et al., 2008). Productivity variation in relation to plant population is associated with the genotype potential to produce fertile tillers, since the sowing density directly influences the number of spikes and/or panicles produced by area (Ozturk et al., 2006). Cultivar selection alone can indicate differences to better fit the population density, due to directly influencing tillering capacity, which is a directly connected component to grain productivity (Valério et al., 2008). Valério et al. (2009) reported that senescence and tillers survival is related to the cultivar tillering potential, since reduced expression genotypes are more dependent on sowing density for maximum grain yield.

The increase in the number of tillers and/or plants per area shows a strong participation in biomass production, which is important to increase dry matter yield (Silveira et al., 2010). Abreu et al. (2002) reported that the increase in white oat plants population resulted in an increase in the culture growth rate and dry matter production per area. Aside from this, the biological yield, which is also called total dry matter, is closely related to photosynthetic and breathing processes during vegetative and reproductive development stages (Demétrio et al., 2012). Thus, the relation between grain yield and biological yield allows the determination of the harvest index $(\mathrm{HI})$, an important parameter when determining the efficiency with which photoassimilates are converted into straw and grains (Silva et al., 2011). Studies have shown that the $\mathrm{HI}$ of a culture is influenced by genotype, sowing density, availability of water, nutrients and temperature (Demétrio et al., 2008).

Continued oats genetic improvements have significantly modified plant architecture by reducing the height, cycle, leaf area, among other features (Crestani, 2011). Therefore, these are changes that can modify cultivars response to plant population, suggesting the need to know the expression of physiological parameters of oats, with the aim to qualify a new planting density recommendation for the current biotype pattern, which is of short cycle and reduced height, found in commercial scale. Even oats technical recommendations (CBPA, 2006) have suggested 200-300 plants $\mathrm{m}^{-2}$, indications that were based on research from a plant biotype with different characteristics than what is recommended today in production systems.

This study seeks to define the ideal sowing density to maximize straw and grain production for the current biotype, which is of short cycle and reduced height, of white oat grown on a commercial scale. Therefore, this study seeks to justify the need of using a seed density that exceeds recommendation.

\section{Material and methods}

The study was conducted in the field during the year of 2011, in the city of Augusto Pestana, RS. The soil of the experimental area is classified as Distrofic Red Latosol and the regional climate, according to Köppen classification, is Cfa, with hot summer without a dry season. In the experiment implementation, about ten days before sowing, soil analysis was carried out in the study conditions, identifying the following site chemical characteristics: i) area with corn residue $\left(\mathrm{pH}-6.5, \mathrm{P}-35.4 \mathrm{mg} \mathrm{dm}^{-3}\right.$, $\mathrm{K}-260 \mathrm{mg} \mathrm{dm}^{-3}, \mathrm{MO}-3.4 \%, \mathrm{Al}-0.0 \mathrm{cmol}_{\mathrm{c}} \mathrm{dm}^{-3}$, $\mathrm{Ca}-6.8 \mathrm{cmol}_{\mathrm{c}} \mathrm{dm}^{-3}$ and $\mathrm{Mg}-3.1 \mathrm{cmol}_{\mathrm{c}} \mathrm{dm}^{-3}$, and ii) area with soybean residue $\left(\mathrm{pH}-6.1, \mathrm{P}-32.9 \mathrm{mg} \mathrm{dm}^{3}\right.$, $\mathrm{K}-200 \mathrm{mg} \mathrm{dm}^{-3}, \mathrm{MO}-3.5 \%, \mathrm{Al}-0.0 \mathrm{cmol}_{\mathrm{c}} \mathrm{dm}^{-3}$, $\mathrm{Ca}-6.3 \mathrm{cmol}_{\mathrm{c}} \mathrm{dm}^{-3}$ and $\left.\mathrm{Mg}-2.5 \mathrm{cmol}_{\mathrm{c}} \mathrm{dm}^{-3}\right)$. Sowing was performed on May 15 with a planter, where each plot consisted of 5 lines with $5 \mathrm{~m}$ length and spacing of $0.20 \mathrm{~m}$, to compose a $5 \mathrm{~m}^{2}$ experimental unit. The seeds of selected genotypes were submitted to the germination and vigor test in the laboratory, in order to correct plant density to the desired population. In the experiments, $80 \mathrm{~kg} \mathrm{ha}^{-1} \mathrm{P}_{2} \mathrm{O}_{5}$ and $60 \mathrm{~kg} \mathrm{~K} 2 \mathrm{O}$ were applied in sowing and $\mathrm{N}$ in the base with $10 \mathrm{~kg} \mathrm{ha}^{-1}$, and the remainder was used to cover an expected yield of about three $\mathrm{t} \mathrm{ha} \mathrm{ha}^{-1}$. During the study execution, tebuconazole fungicide applications were made at a dose of $0.75 \mathrm{~L} \mathrm{ha}^{-1}$. In addition, the weed control was performed with metsulfuron-methyl herbicide, at a dose of $2.4 \mathrm{~g} \mathrm{ha}^{-1}$ of the active ingredient and weeding when necessary.

The experiments were conducted in a randomized block design with four replications, following a factorial $2 \times 4$ for cultivar and viable seed densities per $\mathrm{m}^{2}$. In these sources of variability, the levels of each factor were shown as follows: i) oat cultivars (Brisasul and URS Taura) and; ii) sowing densities (100, 300, 600 and 900 seeds $\mathrm{m}^{-2}$ ). Indicated cultivars represent oat genotypes with release year from 2010, expressing similarity to the cycle (precocious), height (low) and lodging (resistant), but different in tiller production capacity (high - Brisasul and low - URS Taura).

The studies were conducted in two cropping systems, involving soil cover with high and reduced Carbon/Nitrogen ratio plant residue in corn/oats and soybean/oats succession system, respectively. In each system, two experiments were conducted, one for quantifying the biological yield (BY, in $\mathrm{kg} \mathrm{ha}^{-1}$ ), and the 
other aiming solely to the estimation of grain yield (GY, in $\mathrm{kg} \mathrm{ha}^{-1}$ ). The harvest for the estimation of grain yield in each cropping system was performed manually by cutting the three central rows of each plot, which were threshed with a stationary thresher and directed to the laboratory to correct grain moisture to $13 \%$, in addition to weighing to estimate productivity, which was converted to a hectare unit. Furthermore, in experiments to quantify the total biomass, the harvest of plant material was held close to the soil, from the collection of a linear meter of the three central rows of each plot. Afterwards, samples with green biomass were directed to forced air oven at $65^{\circ} \mathrm{C}$ until reaching constant weight, in order to perform total dry matter weight and estimation, which was converted to $\mathrm{kg} \mathrm{ha}^{-1}$. From these measurements, the straw yield (SY in $\mathrm{kg} \mathrm{ha}^{-1}$ ) was estimated by subtracting and the harvest index $\left(\mathrm{HI}, \mathrm{kg} \mathrm{kg}^{-1}\right)$ by division. It is noteworthy that the plots harvest began with the grains at harvest maturity of around $22 \%$ moisture.

Data were subjected to analysis of variance (ANOVA) for the detection of the main and interaction effects of the variation sources on physiological parameters in cropping systems oat production. Subsequently, the means comparison test was performed, through Scott \& Knott clustering model, to quantify the differences and similarities between genotypes in different observation densities. And, finally, polynomial equations were performed in order to define the ideal density, with subsequent estimation of the variable potential expression, in the adjusted density. For all these measurements, Genes computer program was used.

\section{Results and discussions}

The results shown by analysis of variance indicate that the differences attributed to cultivars and sowing densities were effective in changing the characters linked to the physiological performance of white oat production. The interaction effects were also confirmed by identifying distinct behavior on the genetic makeup of evaluated densities, regardless of the succession system (soybean/oat, corn/oat) (Table 1). The observed values of the different systems general means were highlighted, identifying more evident expression increases in soybeans/oats succession in GY and BY characters than on the SY and $\mathrm{HI}$, which showed the closest values between the two culture conditions. This situation reinforces the importance of residual $\mathrm{N}$ availability in the production system and the increased use of the element for oats in GY preparation. The residual soil cover has a number of effects on the development of the subsequent crop, resulting in a greater or lesser capacity of decomposition and nutrient release (Siqueira Neto et al., 2010). In fact, the authors reported that the $\mathrm{C} / \mathrm{N}$ ratio has been the most useful characteristic for simulation models to predict $\mathrm{N}$ availability speed in the soil during decomposition of organic residues. According to Wendling et al. (2007), the cultivation of wheat under soybeans and corn residues show a different development, mainly due to increased availability of residual $\mathrm{N}$ in plants under lower $\mathrm{C} / \mathrm{N}$ ratio condition.

Table 1 - Resume of the analysis of variance of the components grain yield (GY), biological yield (BY), straw yield $(\mathrm{SY})$ and harvest index $(\mathrm{HI})$, related to white oat physiological and production performance.

\begin{tabular}{lccccc}
\hline \multirow{2}{*}{ Variation Source } & \multirow{2}{*}{ (a) DF } & \multicolumn{4}{c}{ Soybean/Oat system - Mean Square } \\
\cline { 3 - 6 } & & GY & BY & SY & HI \\
\hline Block & 3 & 33723 & 394400 & 248672 & 0.00079 \\
Genotype (G) & 1 & $27400^{*}$ & $31312^{*}$ & $117304^{*}$ & $0.00018^{*}$ \\
Density (D) & 3 & $2529675^{*}$ & $3016754^{*}$ & $6258964^{*}$ & $0.07074^{*}$ \\
G x D & 3 & $435525^{*}$ & $1548078^{*}$ & $470667^{*}$ & $0.00127^{*}$ \\
Error & 21 & 73199 & 222262 & 112616 & 0.00079 \\
\hline Total & 31 & - & - & - & - \\
\hline CV (\%) & - & 9.78 & 13.13 & 9.50 & 5.98 \\
General Mean & - & 3079 & 6611 & 3531 & 0.46 \\
\hline Variation Source & (a)DF & & Corn/Oat system - Mean Square & \\
& & GY & BY & SY & HI \\
\hline Block & 3 & 160265 & 514634 & 118145 & 0.00044 \\
Genotype (G) & 1 & $131278^{*}$ & $414732^{*}$ & $79240^{*}$ & $0.00031^{*}$ \\
Density (D) & 3 & $1129013^{*}$ & $3400833^{*}$ & $1064576^{*}$ & $0.00694^{*}$ \\
G x D & 3 & $106293^{*}$ & $952145^{*}$ & $523874^{*}$ & $0.00179^{*}$ \\
Error & 21 & 33232 & 142578 & 75590 & 0.00054 \\
\hline Total & 31 & - & - & - & - \\
\hline (b)CV (\%) & - & 8.86 & 12.49 & 8.69 & 5.07 \\
General Mean & - & 2656 & 5816 & 3160 & 0.45 \\
\hline
\end{tabular}

${ }^{*}$ Significant at 0.05 probability level; ${ }^{(a)} \mathrm{DF}$ - degrees of freedom; ${ }^{(b)} \mathrm{CV}$ - coefficient of variation. 
On Table 2, in the analysis of the behavior of oat cultivars at each observation density, the soybean residue mean showed that the lower density showed no changes on the GY. The difference on this variable was identified in the 300 seeds $\mathrm{m}^{-2}$ section with the URS Taura cultivar, which had a higher behavior than Brisasul, with 3857 and $3257 \mathrm{~kg} \mathrm{ha}^{-1}$, respectively. On the other hand, at a density of 600 seeds $\mathrm{m}^{-2}$, the difference between the two cultivars were not detected, with average productivity values of around $3500 \mathrm{~kg} \mathrm{ha}^{-1}$. At the highest density (900 seeds $\mathrm{m}^{-2}$ ), there was an expressive decrease of URS Taura GY values compared to Brisasul, indicating a higher genotype sensitivity in withstanding high population. Regardless of cultivar, there was a significant $G Y$ reduction in the highest cultivation pressure compared to points of lower density. On the other hand, in a simultaneous analysis of both cultivars, the density of 600 seeds $\mathrm{m}^{-2}$ concurrently indicated higher grain yield. In the corn/oats system (Table 2), GY expression also showed in the 600 seeds $\mathrm{m}^{-2}$ section higher mean values for both cultivars, which have not differed among them in this condition. In this system, the higher density caused a decrease in mean productivity values, especially to the URS Taura cultivar, which is more responsive in GY expression. Despite the official white oat crop recommendation indicating 200-300 viable seeds $\mathrm{m}^{-2}$ in the crop establishment (CBPA, 2006), the pattern biotype of precocious study cycle and reduced stature shows a tendency to increase GY according to increasing sowing density to the point of 600 seeds. In wheat, Zagonel et al. (2002) reported that high plant densities favor increased grain yield. Moreover, interaction effects were also detected, to the point of identifying genotypes that showed to be responsive or not to sowing density increases. Almeida et al. (2003) observed that the crop density from 50 to 500 plants m 2 in obsolete oat cultivars of average to late cycle, which were evaluated in the 1990s, showed little GY contribution. On the other hand, increased sowing density in modern wheat cultivars, mainly in the ones with lower tillering expression, indicated an increase in grain yield (Silveira et al., 2010).

In the BY analysis of soybean/oats system (Table 2), all tested densities showed similar production between the two cultivars, except for the employment of 900 seeds $\mathrm{m}^{-2}$, qualifying Brisasul cultivar in the highest energy conversion ability in total biomass formation. This condition raises the concern about increased genotype stability to crop densities changes, supporting the hypothesis of modifying one or more plant components for the maintenance of this stability. On the other hand, in the corn/oat system (Table 2), BY expression in the lower and higher density (100 and 900 seeds $\mathrm{m}^{-2}$ ) showed differences among cultivars, with URS Taura being above Brisasul. Furthermore, in the points of 300 and 600 seeds $\mathrm{m}^{-2}$, the performance was similar and with high total biomass values. Benin et al. (2005) state the importance of identifying in the species the characters that promote higher changes in the use of environmental stimuli, supporting the ability that some genotypes have in the change plasticity of a character, for the benefit of another. Abreu et al. (2005), while evaluating the white oat and forage legumes consortium, observed that the largest plant populations provided higher biomass production per area. However, in larger oat populations, competition among individuals reduced tillering and biomass per plant. In the UPF 18 late cycle oat, the increase in plant population determined a higher total biomass production per area (Abreu et al., 2006).

In the soybean/oats system in the SY analysis (Table 2), biomass estimation directed to the soil as a protective cover and nutrient release has not differentiated the two cultivars throughout crop densities, except for the highest condition, with higher reposition capacity expressed by Brisasul cultivar. However, in the corn/oats system (Table 2), both in the higher and reduced density, URS Taura cultivar showed the highest production. The strong interaction detected in this system is enhanced by the SY expression similarity among cultivars in the official recommendation density ( 300 seeds $\mathrm{m}^{-2}$ ) and by the behavior change due to the superiority of Brisasul over URS Taura with 600 seeds $\mathrm{m}^{-2}$. Therefore, these results suggest that there is higher stability over SY in a condition of easier residual $\mathrm{N}$ release promoted by soybean residue. Studies by Silva et al. (2008) with different winter species showed white oat high performance in straw yield aimed at soil protection. Oliveira et al. (2011) reported the importance of detecting the genetic differences among cultivars in straw and grain yield, which is a decisive factor in potential genotypes recommendation. Thus, cultivars with high grain and straw expression capacity give gains that qualify economic performance, with benefits to soil quality. In addition, direct seeding system viability is directly dependent on the volume and quality of biomass directed to the soil (Silva et al., 2006). It should be noted that, besides the cultivar efficiency in the use of solar energy, growth and biomass production in oats is strongly linked to $\mathrm{N}$ availability (Silva et al., 2009), which is also dependent of the foliar area, photoperiod, temperature, radiation and water availability indexes (Almeida et al., 2011).

In the $\mathrm{HI}$ analysis of soybean/oat system (Table 2), the difference between the two cultivars in the lowest and highest density points showed the same behavior in straw and grain energy production. However, the 300 seeds $\mathrm{m}^{-2}$ point was decisive in qualifying the URS Taura cultivar as the more efficient targeting of photoassimilates in economic performance formation. In the corn/oats system (Table 2), the two cultivars at 100 and 900 seeds $\mathrm{m}^{-2}$ indicated similarities indicate in this straw/grain relation. On the other hand, at a density of 600 seeds $\mathrm{m}^{-2}$, the URS Taura cultivar showed higher efficiency in developing 
grains. Fageria et al. (2007) commented that the $\mathrm{HI}$ variable is closely associated with increased rice yield, showing the need for its analysis on programs that seek to increase productivity in this species. Therefore, a species $\mathrm{HI}$ indicates the efficiency with which the plant converts the biological yield for grain and straw production. However, a high $\mathrm{HI}$ is not decisive in identifying the most effective management, as an appropriate GY is directly connected to the appropriate minimum total biomass expression by straw. Schaedler et al. (2009), studying white oat, had the highest harvest index in the URS 21 cultivar, with 0.48 , and the lowest index with UPF 16, 0.33.

Table 2 - Mean comparison test for variables related to white oat physiological and production performance over different sowing densities.

\begin{tabular}{|c|c|c|c|c|}
\hline \multirow[t]{2}{*}{ Genotype } & \multicolumn{4}{|c|}{$\begin{array}{c}\text { Soybean/Oats system } \\
\text { (*)Sowing densities (seeds } \mathrm{m}^{-2} \text { ) }\end{array}$} \\
\hline & 100 & 300 & 600 & 900 \\
\hline & \multicolumn{4}{|c|}{ Grain yield (GY, kg ha-1) } \\
\hline Taura & $2687 \mathrm{a}$ & $3857 \mathrm{a}$ & 3667 a & $2222 \mathrm{~b}$ \\
\hline \multirow{2}{*}{ Brisasul } & $2752 \mathrm{a}$ & $3257 \mathrm{~b}$ & $3443 a$ & $2737 a$ \\
\hline & \multicolumn{4}{|c|}{ Biological yield (BY, $\mathrm{kg} \mathrm{ha}^{-1}$ ) } \\
\hline Taura & $5964 \mathrm{a}$ & $7148 \mathrm{a}$ & $6556 a$ & $6649 \mathrm{~b}$ \\
\hline Brisasul & $5756 \mathrm{a}$ & & & 7990 a \\
\hline Tаura & 3276 a & \multicolumn{3}{|c|}{ Straw yield $\left(\mathrm{SY}, \mathrm{kg} \mathrm{ha}^{-1}\right)$} \\
\hline \multirow{2}{*}{ Brisasul } & $3003 \mathrm{a}$ & $3206 \mathrm{a}$ & $2905 a$ & $5252 \mathrm{a}$ \\
\hline & \multicolumn{4}{|c|}{ Harvest index $\left(\mathrm{HI}, \mathrm{kg} \mathrm{kg}^{-1}\right)$} \\
\hline Taura & $0.45 \mathrm{a}$ & $0.54 \mathrm{a}$ & $0.55 \mathrm{a}$ & $0.33 \mathrm{a}$ \\
\hline Brisasul & $0.47 \mathrm{a}$ & $0.50 \mathrm{~b}$ & $0.54 \mathrm{a}$ & $0.34 \mathrm{a}$ \\
\hline \multirow[t]{2}{*}{ Genotype } & \multicolumn{4}{|c|}{$\begin{array}{c}\text { Corn/Oats system } \\
{ }^{(*)} \text { Sowing densities (seeds } \mathrm{m}^{-2} \text { ) }\end{array}$} \\
\hline & 100 & 300 & 600 & 900 \\
\hline & \multicolumn{4}{|c|}{ Grain yield (GY, kg ha-1) } \\
\hline Taura & $2171 \mathrm{a}$ & $2764 \mathrm{a}$ & 3034 a & 2912 a \\
\hline \multirow[t]{2}{*}{ Brisasul } & $2080 \mathrm{a}$ & 2865 a & 2959 a & $2464 \mathrm{~b}$ \\
\hline & \multicolumn{4}{|c|}{ Biological yield (BY, $\mathrm{kg} \mathrm{ha}^{-1}$ ) } \\
\hline Taura & $5174 \mathrm{a}$ & 5731 a & 5989 a & 6828 a \\
\hline \multirow{2}{*}{ Brisasul } & $4573 \mathrm{~b}$ & 6078 a & $6345 \mathrm{a}$ & $5815 \mathrm{~b}$ \\
\hline & \multicolumn{4}{|c|}{ Straw yield $\left(\mathrm{SY}, \mathrm{kg} \mathrm{ha}^{-1}\right)$} \\
\hline Taura & $3002 \mathrm{a}$ & 2966 a & 2954 b & 3916 a \\
\hline Brisasul & $2492 b$ & \multicolumn{2}{|c|}{ Harvest index $\left(\mathrm{HI}, \mathrm{kg} \mathrm{kg}^{-1}\right)$} & $3350 \mathrm{~b}$ \\
\hline Taura & $0.42 \mathrm{a}$ & $0.48 \mathrm{a}$ & $0.50 \mathrm{a}$ & $0.43 a$ \\
\hline Brisasul & $0.45 \mathrm{a}$ & $0.47 \mathrm{a}$ & $0.46 \mathrm{~b}$ & $0.42 \mathrm{a}$ \\
\hline
\end{tabular}

${ }^{(*)}$ Means followed by the same lowercase letter in the column are not statistically different from each other at 0.05 error probability level by Scott \& Knott test.

Seeking to define seed adjusted density to maximize straw and grain production in the cultivated white oat standard biotype, in Tables 3 and 4 the resume of the regression analysis and the equation parameters on the physiological production characters in different cultivation systems are presented. On Table 3, regardless of the succession system, the behavior of URS Taura and Brisasul cultivars in different sowing densities showed significant quadratic tendency in the GY and BY expression and slope degree parameter of two ( $\left.b_{\mathrm{ix}}\right)$, which was also significant. In general, coefficient determination equations are represented in more than $80 \%$ near the tendency line, expressing data reliability. In the soybean/oats system (Table 3), the URS Taura and Brisasul cultivars indicated the highest $G Y$ expression, in the density of 463 and 505 seeds $\mathrm{m}^{-2}$, respectively, with the GY estimated by the model of around $3960 \mathrm{~kg} \mathrm{ha}^{-1}$ in URS Taura and $3483 \mathrm{~kg} \mathrm{ha}^{-1}$ for Brisasul. In this condition, a similar seeds density adjustment between the two cultivars was observed. However, grain yield expression efficiency was higher on URS Taura than on Brisasul. Moreover, in the GY analysis of corn/oats system (Table 3), the difference in seeds amount between the two cultivars was significant, with the optimum density under this condition being of around 653 to 547 seeds $\mathrm{m}^{-2}$ in URS Taura and Brisasul cultivars, respectively. However, such conditions come from a grain yield estimated by similar model between the two cultivars, in the order of $3080 \mathrm{~kg} \mathrm{ha}^{-1}$ for URS Taura and $3060 \mathrm{~kg} \mathrm{ha}^{-1}$ for Brisasul. Thus, in a more restrictive condition of the residual $\mathrm{N}$ by corn/oats system, the larger quantity of seeds in URS Taura was 
necessary, and higher stability of Brisasul genotype compared to both culture systems was detected. Valério et al. (2009) mentioned that the GY response to the increased plants density depends on morphological, physiological and allometric compensation gaps mechanisms between plants. Grasses have high compensation ability under reduced population, which was attributed to large production capacity and tillers development. Therefore, the competition effect between plants is critical in tillers production, with direct implications on grain yield and its components (Ozturk et al., 2006).

Table 3 - Resume of the regression variance analysis and equation parameters depending on sowing density ( $\mathrm{x}$ ) for grain yield (GY) and biological yield (BY).

\begin{tabular}{|c|c|c|c|c|c|c|c|}
\hline Cultivar & (a) VS & (b)MS & $\begin{array}{c}\mathrm{GY}=\mathrm{a} \pm \mathrm{bx} \pm \mathrm{cx}^{2} \\
\text { Grain yield }\end{array}$ & (c) $\mathrm{R}^{2}$ & $\begin{array}{l}\text { (d) } P \\
\text { (bix) }\end{array}$ & $\begin{array}{c}(\mathrm{e}) \mathrm{D} \\
\left(\text { seed } \mathrm{m}^{-2}\right)\end{array}$ & $\begin{array}{c}\text { GY } \\
\left(\mathrm{kg} \mathrm{ha}^{-1}\right)\end{array}$ \\
\hline \multirow{4}{*}{ Taura } & & & Soybean/Oats system & & & \multirow{4}{*}{463} & \multirow{4}{*}{3960} \\
\hline & (f) $\mathrm{L}$ & $851629 *$ & $3470.4-0.761 x$ & 0.67 & ns & & \\
\hline & (g) $Q$ & $6338265^{*}$ & $1992+8.51 x-0.0092 x^{2}$ & 0.97 & * & & \\
\hline & (h) $E$ & 53720 & - & - & - & & \\
\hline \multirow{3}{*}{ Brisasul } & (f) $\mathrm{L}$ & $1194^{\mathrm{ns}}$ & - & - & - & \multirow{3}{*}{505} & \multirow{3}{*}{3483} \\
\hline & ${ }^{(g)} \mathrm{Q}$ & $1548396^{*}$ & $2333+4.55 x-0.0045 x^{2}$ & 0.99 & * & & \\
\hline & (h) $E$ & 89439 & - & - & - & & \\
\hline \multirow{4}{*}{ Taura } & & & Corn/Oats system & & & \multirow{4}{*}{653} & \multirow{4}{*}{3080} \\
\hline & (f) $L$ & $1109002^{*}$ & $2308+0.86 x$ & 0.71 & ns & & \\
\hline & (g) $Q$ & $629748^{*}$ & $1842+3.79 x-0.0029 x^{2}$ & 0.99 & * & & \\
\hline & (h) $E$ & 24216 & - & - & - & & \\
\hline \multirow{3}{*}{ Brisasul } & (f) $L$ & $200446^{\text {ns }}$ & - & - & - & \multirow{3}{*}{547} & \multirow{3}{*}{3060} \\
\hline & ${ }^{(g)} Q$ & $1683980^{*}$ & $1655+5.14 x-0.0047 x^{2}$ & 0.96 & * & & \\
\hline & (h) $\mathrm{E}$ & 49373 & & & & & \\
\hline Cultivar & (a) VS & (b)MS & $\begin{array}{l}\mathrm{BY}=\mathrm{a} \pm \mathrm{bx} \pm \mathrm{cx} \mathrm{x}^{2} \\
\text { Biological yield }\end{array}$ & $\mathrm{R}^{2}$ & $\begin{array}{l}(d) P \\
\left(b_{i x}\right)\end{array}$ & $\begin{array}{c}{ }^{(e)} \mathrm{D} \\
\left(\text { seed } \mathrm{m}^{-2}\right)\end{array}$ & $\begin{array}{c}\text { BY } \\
\left(\mathrm{kg} \mathrm{ha}^{-1}\right) \\
\end{array}$ \\
\hline \multirow{4}{*}{ Taura } & & & Soybean/Oats system & & & \multirow{4}{*}{567} & \multirow{4}{*}{6936} \\
\hline & (f) $L$ & $271996^{\text {ns }}$ & $6375+0.43 x$ & - & - & & \\
\hline & (g) $Q$ & $926456^{*}$ & $5810+3.97 x-0.0035 x^{2}$ & 0.82 & * & & \\
\hline & (h) $\mathrm{E}$ & 220901 & - & - & - & & \\
\hline \multirow{3}{*}{ Brisasul } & (f) $L$ & $8774498^{*}$ & $5481+2.44 x$ & 0.41 & ns & \multirow{3}{*}{514} & \multirow{3}{*}{6100} \\
\hline & (g) $Q$ & 737989* & $6286-0.72 x+0.0007 x^{2}$ & 0.83 & * & & \\
\hline & (h) $\mathrm{E}$ & 184081 & - & - & - & & \\
\hline \multirow{4}{*}{ Taura } & & & Corn/Oats system & & & \multirow{4}{*}{630} & \multirow{4}{*}{5704} \\
\hline & (f) $L$ & $5450830 *$ & $5016+1.92 x$ & 0.78 & ns & & \\
\hline & ${ }^{(g)} Q$ & $25387^{\text {ns }}$ & $5109+1.33 x+0.0005 x^{2}$ & 0.96 & * & & \\
\hline & (h) $\mathrm{E}$ & 133371 & - & - & - & & \\
\hline \multirow{3}{*}{ Brisasul } & (f) $\mathrm{L}$ & $2571369^{*}$ & $5074+1.32 x$ & 0.76 & ns & \multirow{3}{*}{591} & \multirow{3}{*}{6522} \\
\hline & (g) $Q$ & $4466407^{*}$ & $3833+9.10 x-0.0077 x^{2}$ & 0.95 & * & & \\
\hline & (h) $\mathrm{E}$ & 143474 & & & & & \\
\hline
\end{tabular}

a)VS - variation source; (b)MS - mean square; ${ }^{(c)} R^{2}$ - coefficient of determination; ${ }^{(d)} \mathrm{P}\left(\mathrm{b}_{\mathrm{ix}}\right)$ - parameter that measures the statistical significance of linear coefficient of the equation at a $5 \%$ probability level; (e) $D$ - sowing density; (f) $L$ - linear; ${ }^{(g)} \mathrm{Q}$ - quadratic; (h)E - Experimental error; ${ }^{\mathrm{ns}}$ not statistically significant at 0.05 level of error probability; ${ }^{*}$ statistically significant at 0.05 level of error probability.

The use of an appropriate density allows a species to grow faster and covers the ground more efficiently, causing less weeds interference (Fleck et al., 2009). This condition is fundamentally important in a species such as oats, in which interspecific competition with ryegrass (Lolium multiflorum L.) is harmful, especially when dealing with the lack of the chemical molecule that allows selective control. Silveira et al. (2010), while studying wheat, found considerable increase in grain yield with the increase of sowing density, with values between 500 and 600 seeds $\mathrm{m}^{-2}$, much higher than suggested by the technical indication of this species. In addition, Valério et al. (2008) were already reporting that precocious wheat genotypes with reduced tillering potential were more dependent on the correct adjustment of sowing density, suggesting at higher values the recommendation to leverage the grain yield.

The total biomass (BY) in the soybean/oats system (Table 3) indicated that the ideal density on URS Taura cultivar was obtained with 567 seeds $\mathrm{m}^{-2}$, with estimated productivity of $6936 \mathrm{~kg} \mathrm{ha}^{-1}$. In Brisasul, the 
ideal density in this condition was of 514 seeds $\mathrm{m}^{-2}$, with maximum production estimation of around $6100 \mathrm{~kg} \mathrm{ha}^{-1}$. It is noted that, for Brisasul, adjusted seed density was similar for both the GY and BY, regardless of culture system. This was also observed in the URS Taura cultivar in the corn/oats system, with maximum BY expression of around 630 seeds $\mathrm{m}^{-2}$, similar density seeking the maximum GY expression in this system. Adjusted seed density in this cultivar BY expression in the corn/oats system promoted a productivity estimate of around $5704 \mathrm{~kg} \mathrm{ha}^{-1}$. In this condition, Brisasul cultivar indicated an adjusted density of 591 seeds $\mathrm{m}^{-2}$ and estimated productivity of $6522 \mathrm{~kg} \mathrm{ha}^{-1}$. It is important to mention that the adjusted values of seed density were similar to those found to maximize GY expression in corn/oats system. Therefore, the most favorable residual $\mathrm{N}$ release condition by soybean residue shows favoritism in BY expression of URS Taura cultivar. Moreover, higher BY stability of expression was noted by Brisasul in the comparison of the two cultivation systems, which was also similar when analyzing GY. Proper sowing density, besides promoting higher grain yield, can enhance the biomass area ${ }^{-1}$, provided that there is no plant lodging (Valério et al., 2008). Abreu et al. (2002) observed that the biomass production in late cycle oat has quadratic tendency, with maximum population point of 306 plant $\mathrm{m}^{-2}$ and the estimated productivity of $8889 \mathrm{~kg} \mathrm{ha}^{-1}$. Besides that, Abreu et al. (2006) noted that the sowing time and the cultivars cycle showed significant effect on biomass production, directly interacting in the best population density adjustment. Increased competition between plants caused a morphological adaptation that improved light, water and nutrients use, with expressed benefits to $B Y$ formation. In white oat, the light interception capacity in the canopy and the plant population and arrangement is a function of tillering capacity, plant height, leaves number and distribution, limbo decumbent degree, shoot dry matter and area and foliar angle (Schaedler et al., 2009).

In Table 4, regardless of cultivar and succession system, sowing densities promoted quadratic tendency in SY and $\mathrm{HI}$ expression, with equations validity by slope degree parameter significance of two (bix). Determination coefficients were also represented in over $80 \%$ near tendency line, aiming at results reliability. In soybean/oats system (Table 4), the maximum straw yield (SY) was in the density of 404 and 347 seeds $\mathrm{m}^{-2}$ for URS Taura and Brisasul cultivars, respectively, showing in this order an estimated SY of 2901 and 2739 kg ha-1, respectively. Regardless of tested conditions, the SY expression in the adjusted density showed to be reduced compared to $G Y$ and $B Y$. This condition reinforces the importance of increasing the sowing density to bring changes that favor mainly GY expression. In corn/oats system, a similar condition was also observed, showing increased straw yield in the URS Taura and Brisasul cultivars, in the density of 360 and 498 seeds $\mathrm{m}^{-2}$, respectively. Therefore, the formulated equation aims for an estimated SY i the adjusted density of 2825 and $3146 \mathrm{~kg} \mathrm{ha}^{-1}$, respectively. The high straw presence in the soil is essential to promote nutrient cycling, metals complexation and microbial activity. Thus, the straw cover acts as elements replenisher to plants by degradation of decomposition tissues (Braida et al., 2006). In this context, the high adaptability of white oat and its multiple purposes, including the quality of residual cover, reflect on its importance in production systems sustainability (Castro et al., 2012). In wheat, the sowing density increase of 100 to 200 plants per m2 considerably decreased the presence of weeds and increased grain and straw yield by this species (Lemerle et al., 2004).

In the $\mathrm{HI}$ analysis of soybean/oats system (Table 4), the total biomass ratio converted to grains shows adjusted density similarity between URS Taura and Brisasul cultivars of around 416 and 441 seeds m2 , respectively. However, URS Taura had a higher $\mathrm{HI}$ value, 0.57 , compared to Brisasul, 0.54 . This fact shows the increased physiological efficiency of URS Taura in soybean/oats system because, besides expressing the highest BY compared to Brisasul, it also showed a higher energy directing in grain formation, thus corroborating with the largest $\mathrm{HI}$ and GY. In the corn /oats system, URS Taura cultivar showed $0.50 \mathrm{HI}$ in the adjusted density of 509 seeds $\mathrm{m}^{-2}$. Therefore, it was higher than Brisasul $\mathrm{HI}$ maximum expression, which was of 0.46 , with adjusted density of 405 seeds $\mathrm{m}^{-2}$. This situation shows the higher ability to increase seeds amount in the URS Taura, seeking to leverage HI. This condition is reinforced by evidencing in this system a similar GY to Brisasul, but with smaller BY, which favored a higher HI. Therefore, URS Taura efficiency in this condition does not concomitantly result in higher GY and $B Y$, and a particular analysis that only uses HI may subjugate Brisasul higher efficiency, which showed reduced $\mathrm{HI}$ due to higher $\mathrm{BY}$ expression. Thus, in the corn/oats system, a better adjustment of Brisasul cultivar is observed in the development of grain with high straw yield. Studies have shown that a culture $\mathrm{HI}$ is markedly influenced by planting density, availability of water, nutrients and temperature in the growing season (Ludwig et al., 2010). Silva et al. (2011) commented about the $\mathrm{HI}$ advantage in plant selection process or in the identification of more adjusted managements, indicating the efficiency with which the plant converts BY to straw and grain yield. Barbosa Neto et al. (2000), while analyzing the $\mathrm{HI}$ of 15 white oat cultivars observed reduced variability in the character and detected a mean value of around 0.37 . On the average, regardless of cultivar, sowing density and cultivation system, the $\mathrm{HI}$ value was around 0.46 . In addition, when considering the possibility of improving the environment through seed density adjustment, the $\mathrm{HI}$ was increased to 0.52 . These results show oats genetic improvement advances in increased grain yield, with stature cultivars and lower cycle, resulting in reduced biomass via straw, highlighting the need of genotype versus environment interaction adjustment by planting density. Studies have 
shown that the expression of agronomically important characters in oats, including $\mathrm{HI}$, is markedly influenced by planting density (Abreu et al., 2006). In some soybean cultivars, increased line seed density has not improved HI. However, the BY per area was increased
(Ludwig et al., 2010). In corn, the sowing density increase provided a higher $\mathrm{HI}$, maintaining or improving the quality of grains in the tested cultivars (Demétrio et al., 2008).

Table 4 - Resume of the regression variance analysis and equation parameters depending on sowing density $(x)$ for straw yield (SY) and harvest index $(\mathrm{HI})$.

\begin{tabular}{|c|c|c|c|c|c|c|c|}
\hline Cultivar & (a) VS & (b) MS & $\begin{array}{c}\text { SY }=a \pm b x \pm c x^{2} \\
\text { Straw yield }\end{array}$ & ${ }^{(c)} R^{2}$ & $\begin{array}{l}(d) P \\
\left(b_{i x}^{2}\right)\end{array}$ & $\begin{array}{c}(e) \mathrm{D} \\
\left(\text { seed } \mathrm{m}^{-2}\right)\end{array}$ & $\begin{array}{c}\text { SY } \\
\left(\mathrm{kg} \mathrm{ha}^{-1}\right)\end{array}$ \\
\hline Taura & $\begin{array}{l}\text { (f) } \mathrm{L} \\
\text { (g) } \mathrm{Q} \\
\text { (h) } \mathrm{E}\end{array}$ & $\begin{array}{c}2085122^{*} \\
2417437^{*} \\
80849\end{array}$ & $\begin{array}{c}\text { Soybean/Oats system } \\
2905+1.19 x \\
3818-4.53 x+0.0056 x^{2} \\
-\end{array}$ & $\begin{array}{l}0.52 \\
0.85 \\
-\end{array}$ & $\begin{array}{l}\text { ns } \\
* \\
-\end{array}$ & 404 & 2901 \\
\hline Brisasul & $\begin{array}{l}\text { (f) } \mathrm{L} \\
\text { (g) } \mathrm{Q} \\
\text { (h) } \mathrm{E}\end{array}$ & $\begin{array}{c}8980552^{*} \\
4425365^{\star} \\
143250\end{array}$ & $\begin{array}{c}2417+2.47 x \\
3653-5.27 x+0.0076 x^{2} \\
-\end{array}$ & $\begin{array}{l}0.61 \\
0.89 \\
-\end{array}$ & $\begin{array}{l}\text { ns } \\
* \\
-\end{array}$ & 347 & 2739 \\
\hline Taura & $\begin{array}{l}\text { (f) } \mathrm{L} \\
\text { (g) } \mathrm{Q} \\
\text { (h) } \mathrm{E}\end{array}$ & $\begin{array}{c}1643315^{*} \\
907532^{*} \\
75124\end{array}$ & $\begin{array}{c}\text { Corn/Oats system } \\
2707+1.05 x \\
3267-2.45 x+0.0034 x^{2}\end{array}$ & $\begin{array}{l}0.64 \\
095\end{array}$ & $\begin{array}{l}\text { ns } \\
\text { * }\end{array}$ & 360 & 2825 \\
\hline Brisasul & $\begin{array}{l}(\mathrm{f}) \mathrm{L} \\
(\mathrm{g}) \mathrm{Q}\end{array}$ & $\begin{array}{r}1335957^{*} \\
665374^{*}\end{array}$ & $\begin{array}{c}2657+0.95 x \\
2178+3.95 x-0.0029 x^{2}\end{array}$ & $\begin{array}{l}0.41 \\
0.73\end{array}$ & $\begin{array}{l}\text { ns } \\
\text { * }\end{array}$ & 498 & 3146 \\
\hline Cultivar & (a) VS & $\frac{68131}{\text { (b)MS }}$ & $\begin{array}{l}- \\
\mathrm{HI}=\mathrm{a} \pm \mathrm{bx} \pm c \mathrm{x}^{2} \\
\text { Harvest index }\end{array}$ & (c) $\mathrm{R}^{2}$ & $\begin{array}{c}- \\
\left(\mathrm{d}^{\prime} \mathrm{P}\right. \\
\left(\mathrm{b}_{\mathrm{ix}}{ }^{2}\right)\end{array}$ & $\begin{array}{c}{ }^{(\mathrm{e})} \mathrm{D} \\
\left(\text { seed } \mathrm{m}^{-2}\right)\end{array}$ & 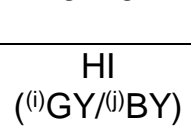 \\
\hline Taura & $\begin{array}{l}\text { (f) } \mathrm{L} \\
(\mathrm{g}) \mathrm{Q} \\
{ }^{(\mathrm{h})} \mathrm{E} \\
(\mathrm{f}) \mathrm{L}\end{array}$ & $\begin{array}{l}0.0318^{*} \\
0.0932^{*} \\
0.0002 \\
0.0310^{\star}\end{array}$ & $\begin{array}{c}\text { Soybean/Oats system } \\
0.54-0.00014 x \\
0.36+0.00097 x-0.0000011 x^{2} \\
- \\
0.53-0.00014 x\end{array}$ & $\begin{array}{l}0.77 \\
0.98 \\
- \\
0.69\end{array}$ & $\begin{array}{c}\mathrm{ns} \\
\text { * } \\
- \\
\text { ns }\end{array}$ & 441 & 0.57 \\
\hline Brisasul & $\begin{array}{l}\text { (g) } \mathrm{Q} \\
\text { (h) } \mathrm{E}\end{array}$ & $\begin{array}{l}0.0518^{*} \\
0.0014\end{array}$ & $\begin{array}{c}0.40+0.00069 x-0.00000083 x^{2} \\
- \\
\text { Corn/Oats System }\end{array}$ & 0.92 & * & 416 & 0.54 \\
\hline Taura & $\begin{array}{l}\text { (f) } L \\
\text { (g) } Q \\
\text { (h) } E \\
\text { (f) } L\end{array}$ & $\begin{array}{l}0.00019^{\text {ns }} \\
0.02080^{*} \\
0.00037 \\
0.0018042^{\text {ns }}\end{array}$ & $0.37+0.00054 x-0.00000053 x^{2}$ & $0 . \overline{9}$ & * & 509 & 0.50 \\
\hline Brisasul & $\begin{array}{l}\text { (g) } \mathrm{Q} \\
\text { (h) } \mathrm{E}\end{array}$ & $\begin{array}{l}0.0033167^{\star} \\
0.0007555\end{array}$ & $0.43+0.00017 x-0.00000021 x^{2}$ & 0.99 & * & 405 & 0.46 \\
\hline
\end{tabular}

(a)VS - variation source; (b)MS - mean square; (c) $\mathrm{R}^{2}$ - coefficient of determination; ${ }^{(\mathrm{d})} \mathrm{P}\left(\mathrm{b}_{\mathrm{ix}}{ }^{2}\right)$ - parameter that measures the statistical significance of linear coefficient of the equation at a $5 \%$ probability level; (e) $\mathrm{D}$ - sowing density; ( ${ }^{(f)} \mathrm{L}$ - linear; ${ }^{(g)} \mathrm{Q}$ - quadratic; (h) $\mathrm{E}$ - experimental error; (i) $\mathrm{GY}$ - grain yield; () $\mathrm{BY}$ - biological yield; ns not statistically significant at 0.05 level of error probability; ${ }^{*}$ statistically significant at 0.05 level of error probability.

However, the results obtained from the information analyzed in other species come to justify the need for more effective criteria related to sowing density, especially in oat front to the changes occurring in the formation of the current standard grown biotype. Therefore, there is the need of a management technique that does not increase production costs and may allow improvements in straw and grain yield, with benefits of rapid soil cover in weed control, reducing the use of pesticides.

\section{Conclusions}

Regardless of the tested genotypes and the current cropping system, the cultivated white oat standard biotype shows in production physiological characters sowing density adjusted to around 500 seeds $\mathrm{m}^{-2}$.
The results show that the proposed seed recommendation, which exceeds the technical oat indications in the main cultivated biotype, besides increasing grain yield, can bring benefits in qualifying crop management.

\section{Acknowledgments}

To Conselho Nacional de Desenvolvimento Científico e Tecnológico (CNPq), , Fundação de Amparo a Pesquisa do Estado do Rio Grande do Sul (FAPERGS) and Universidade Regional do Noroeste do Estado do Rio Grande do Sul (UNIJUI) for the inflow of funds intended to develop this study and for the Grants of Scientific Initiation and Technical Support, Graduation and Research Productivity. 


\section{References}

Abreu GT, Schuch LOB, Maia MS (2002) Análise do crescimento e utilização de nitrogênio em aveia branca (Avena sativa L.) em função da população de plantas. Revista Brasileira de Agrociência, 8(2): 111-116.

Abreu GT, Schuch LOB, Maia MS, Rosenthal MD, Bacchi S, Pereira E, Cantarelli LD (2005) Produção de biomassa em consórcio de aveia branca (Avena sativa L.) e leguminosas forrageiras. Revista Brasileira de Agrociência, 11(1): 19-24.

Abreu GT, Schuch LOB, Maia MS, Rosenthal MD, Bacchi S, Nunes EP, Cantarelli LD (2006) Efeito da população de plantas do cultivar UPF 18 de aveia branca (Avena sativa L.) sobre a produção de biomassa. Revista Brasileira de Agrociência, 12(1): 31-36.

Almeida ML, Sangoi L, Ender M, Wamser AF (2003) O afilhamento não interfere na resposta do rendimento de grãos de aveia à densidade de plantas. Scientia Agricola, 60(2): 253-258.

Almeida ACS, Mingoti R, Coelho RD, Lourenço LF (2011) Simulação do crescimento do capim Tanzânia irrigado com base na unidade fototérmica, na adubação nitrogenada e na disponibilidade hídrica do período. Acta Scientiarum Agronomy, 33(2): 215-222. doi:10.1590/S0103-90162003000200008

Barbosa Neto JF, Matiello RR, Carvalho FIF, Oliveira JMS, Pegoraro DG, Schneider F, Sordi MEB, Vacaro E (2000) Progresso genético no melhoramento da aveia-branca no sul do Brasil. Pesquisa Agropecuária Brasileira, 35(8):1605-1612. doi:10.1590/S0100204X2000000800013

Benin G, Carvalho FIF, Oliveira AC, Lorencetti C, Vieira EA, Coimbra JLM, Valério IP, Floss EL, Bertan I, Silva GO (2005) Adaptabilidade e estabilidade em aveia em ambientes estratificados. Ciência Rural, 35(2): 295-302. doi:10.1590/S0103-84782005000200008

Braida JA, Reichert JM, Veiga M, Reinert DJ (2006) Resíduos vegetais na superfície e carbono orgânico do solo e suas relações com a densidade máxima obtida no ensaio proctor. Revista Brasileira de Ciência do Solo, 30(4): 605-614. doi:10.1590/S010006832006000400001

Castro GSA, Costa CHM, Neto JF (2012) Ecofisiologia da aveia branca. Scientia Agraria Paranaensis, 11(3): $1-15$.

CBPA - Comissão Brasileira de Pesquisa de Aveia (2006) Indicações Técnicas para Cultura da Aveia. Guarapuava: A comissão: Fundação Agrária de Pesquisa Agropecuária, 82p.

Crestani, M. (2011) Interação genótipo vs. ambiente e capacidade combinatória para caracteres de interesse agronômicos na cultura da aveia branca (Avena sativa L.). UFPel (Tese de Doutorado em Agronomia), $201 \mathrm{p}$.
Demétrio CS, Fornasieri Filho D, Cazetta JO, Cazetta DA (2008) Desempenho de híbridos de milho submetidos a diferentes espaçamentos e densidades populacionais. Pesquisa Agropecuária Brasileira, 43(12): 1691-1697. doi:10.1590/S0100204X2008001200008

Demétrio JV, Costa ACT, Oliveira PSR (2012) Produção de biomassa de cultivares de aveia sob diferentes manejos de corte. Pesquisa Agropecuária Tropical, 42(2): 198-205.

Fageria NK, Santos AB, Cutrim VA (2007) Produtividade de arroz irrigado e eficiência de uso do nitrogênio influenciadas pela fertilização nitrogenada. Pesquisa Agropecuária Brasileira, 42(7): 1029-1034. doi:10.1590/S0100-204X2007000700016

Fleck NG, Schaedler CE, Agostinetto D, Rigoli RP, Dal Magro T, Tironi SP (2009) Associação de características de planta em cultivares de aveia com habilidade competitiva. Planta Daninha, 27(2): 211220. doi:10.1590/S0100-83582009000200001

Lemerle D, Cousens RD, Gill GS, Peltzer SJ, Moerkerk M, Murphy CE, Collins D, Cullis BR (2004) Reliability of higher seeding rates of wheat for increased competitiveness with weeds in low rainfall environments. Journal of Agricultural Science, 142(4): 395-409. doi;10.1017/S002185960400454X

Ludwig MP, Dutra LMC, Lucca Filho AO, Zabot L, Uhry D, Lisboa JI, Jauer A (2010) Características morfológicas de cultivares de soja convencionais e Roundup Ready ${ }^{\top M}$ em função da época e densidade de semeadura. Ciência Rural, 40(4): 759-767. doi:10.1590/S0103-84782010000400003

Oliveira AA, Pittelkow FK, Jakelaitis A, Santos CL, Gil JO, Borchartt L (2011) Produção de grãos e forragem na consorciação de cultivares de milho e capins. Global Science and Technology, 4(2): 58-67.

Ozturk A, Caglar O, Bulut S (2006) Growth and yield response of facultative wheat to winter sowing, freezing sowing and spring sowing at different seeding rates. Journal of Agronomy and Crop Science, 192(1): 10-16.

doi:10.1111/j.1439-037X.2006.00187.X

Schaedler CE, Fleck NG, Ferreira FB, Lazaroto CA, Rizzardi MA (2009) Características morfológicas em plantas de cultivares de aveia como indicadoras do potencial competitivo com plantas daninhas. Ciência Rural, 39(5): 1313-1319. doi:10.1590/S010384782009005000065

Silva EC, Muraoka T, Buzetti S, Trivelin PCO (2006) Manejo de nitrogênio no milho sob plantio direto com diferentes plantas de cobertura, em latossolo vermelho. Pesquisa Agropecuária Brasileira, 41(3): 477-486. doi:10.1590/S0100-204X2006000300015. 
Silva AA, Silva PRF, Sangoi L, Piana AT, Strieder ML, Jandrey DB, Endrigo PC (2008) Produtividade do milho irrigado em sucessão a espécies invernais para produção de palha e grãos. Pesquisa Agropecuária Brasileira, 43: 987-993. doi:10.1590/S0100204X2008000800006

Silva MAG, Porto SMA, Mannigel AR, Muniz AS, Mata JDV, Numoto AY (2009) Manejo da adubação nitrogenada e influência no crescimento da aveia preta e na produtividade do milho em plantio direto. Acta Scientiarum Agronomy, 31(2): 275-281. doi:10.1590/S1807-86212009000200014

Silva JAG, Bandeira TP, Manjabosco CD, Krüger CAMB, Silva DAS, Crestani M, Carbonera R (2011) Caracterização e herdabilidade em caracteres morfológicos e fisiológicos da mamona. Revista Brasileira de Agrociência, 17(3-4): 348-358.

Silveira G, Carvalho FIF, Oliveira AC, Valério IP, Benin G, Ribeiro G, Crestani M, Luche HS, Silva JAG (2010) Efeito da densidade de semeadura e potencial de afilhamento sobre a adaptabilidade e estabilidade em trigo. Bragantia, 69(1): 63-70. doi:10.1590/S0006-87052010000100009

Siqueira Neto M, Scopel E, Corbeels M, Cardoso AN, Douzet J, Feller C, Piccolo MC, Cerri CC, Bernoux M (2010) Soil carbon stocks under no-tillage mulchbased cropping systems in the Brazilian Cerrado: An on-farm synchronic assessment. Soil \& Tillage Research, 110(1): 187-195. doi:10.1016/j.still.2010.07.010
Valério IP, Carvalho FIF, Oliveira AC, Machado AA, Benin G, Scheeren PL, Souza VQ, Hartwig I (2008) Desenvolvimento de afilhos e componentes do rendimento em genótipos de trigo sob diferentes densidades de semeadura. Pesquisa Agropecuária Brasileira, 3(43): 319-326. doi:10.1590/S0100204X2008000300005.

Valério IP, Carvalho FIF, Oliveira AC, Benin G, Maia LC, Silva JAG, Schmidt DM, Silveira G (2009) Fatores relacionados à produção e desenvolvimento de afilhos em trigo. Semina: Ciências Agrárias, 30(1): 1207-1218. doi:10.5433/1679-

0359.2009v30n4Sup1p1207

Wendling A, Eltz FLF, Cubilla MM, Amado TJC, Mielniczuk J, Lovato T (2007) Recomendação de adubação nitrogenada para trigo em sucessão ao milho e soja sob sistema plantio direto no Paraguai. Revista Brasileira Ciência Solo, 31(5): 985-994. doi:10.1590/S0100-06832007000500015

Zagonel J, Venancio WS, Kunz RP, Tanamati H (2002) Doses de nitrogênio e densidades de plantas com e sem regulador de crescimento afetando o trigo, cultivar OR-1. Ciência Rural, 32(1): 25-29. doi:10.1590/S0103-84782002000100005 